\begin{tabular}{|c|c|c|c|}
\hline \multirow{2}{*}{$\begin{array}{c}\text { LARUS } \\
\text { Hrvatska akademija } \\
\text { znanosti i umjetnosti }\end{array}$} & 51 & $\begin{array}{c}17-24 \text { str. } \\
1 \text { slika }\end{array}$ & Zagreb 2016 \\
\cline { 2 - 4 } & $(2016)$ & \multicolumn{3}{|c|}{$\begin{array}{c}\text { Primljeno 1. 9. 2016. } \\
\text { Prihvaćeno na sjednici Razreda za prirodne znanosti HAZU 24.10.2016. }\end{array}$} \\
\hline
\end{tabular}

UDK 598.282/.299

Original scientific paper

Izvorni znanstveni članak

DOI: http://doi.org/10.21857/moxpjhoqem

\title{
A LONG-TERM STUDY OF EGG DIMENSIONS IN THE TREE SPARROW Passer montanus IN RELATION TO CLIMATE CHANGE
}

\section{Dugogodišnje istraživanje dimenzija jaja populacije poljskog vrapca Passer montanus u odnosu na klimatske promjene}

\author{
Zdravko Dolenec \\ Mokrice 132, HR-49243 Oroslavje, Croatia
}

\begin{abstract}
Recent studies have illustrated that increasing temperatures have had considerable effects on species and entire ecosystems. In this study I examine long-term trends of egg dimensions (length, breadth and volume) in the population of Tree Sparrows (Passer montanus), investigated during 36 years (1980-2015), in relation to spring temperatures. This species is a common, sedentary, hole-nesting and socially monogamous passerine bird in research area. Research took place in Mokrice area in north-western Croatia. Average temperatures in spring (mean March-April) have significantly increased during the monitored period of time. In population in north-western Croatia there was no increase or decrease in egg dimensions. Correlations between mean spring temperatures and mean egg length, and egg breadth and egg volume were not significant. Spring precipitations (March-April) did not change over the years and did not affect egg dimensions. Data on changes in egg dimensions are relatively scarce in comparison with data on other breeding parameters in birds and, in some cases, controversial; some authors report increase in egg dimensions while others report decreases in egg dimensions in different bird species and populations as a response to climate warming. Thus, changes in egg dimension are a very complex issue in bird demography because there are many traits apart from climate that have impact on egg size, such as female condition, genetic
\end{abstract}

e-mail: dolenec@biol.pmf.hr 
and habitat characteristics etc., so further investigations on this subject are necessary.

Keywords: Tree Sparrow, Passer montanus, egg dimensions, spring temperature, spring precipitation, north-western Croatia

\section{INTRODUCTION}

Global mean temperature has increased by more than $0.75^{\circ} \mathrm{C}$ during the last century (IPCC 2007). Meta-analyses and other studies have illustrated that increasing temperatures have had considerable effects on many organisms in the world. For instance, higher spring temperatures have led to the earlier emergence of yellow-belied marmots (Marmota flaviventris) from hibernation in the USA (INOUYE et al. 2000) and warmer air temperatures are associated with earlier spawning by amphibians (TRYJANOwsKi et al. 2003). Increasing evidence suggests that climate change has consequences on birds. Numerous papers have reported changes in breeding phenology (e.g. Dunn \& WinkLer 1999, D'Alba et al. 2010; Dolenec \& Dolenec 2011a, Dolenec et al. 2012) and migration phenology (e.g. Kralj \& Dolenec 2008, Dolenec \& Dolenec 2010b). On the other hand, some bird species have not changed their arrival dates or laying dates during approximately the last 30 years (Weidinger \& Kral 2007, Dolenec 2012, Dolenec 2013a, Dolenec 2015). Furthermore, recent climate warming has been shown to affect the distribution of different species (e.g. Thomas \& Lennon 1999, Jiménez-VALVERDE et al. 2011). The impacts of climate change on demographic factors, breeding performance and survival, which affect the population dynamics of species, have been less well explored than phenology; several studies have shown trends in various aspects of breeding performance that correlate with trends in climate (CRICK 2004). Some studies documented increased brood size (e.g. HUŠEK \& ADAmík 2008, Dolenec 2009), while others reported changes in clutch size (e.g. Järvinen 1996, MølLER 2002). Furthermore, some papers reported changes in egg size (e.g. Ротti 2008, Barret et al. 2012).

In this study, I have examined long-term trends of egg dimensions (length, breadth and volume) in a population of Tree Sparrows (Passer montanus) during 36 years in relation to climate parameters (mean spring temperatures and precipitations) and research period (1980-2015). The size of eggs to lay is one of the first problems that an individual bird faces at the beginning of the reproductive cycle (HõraK et al. 1995), and large eggs produce large offspring which may grow and survive more successfully than offspring hatched from small eggs (e.g. WiLIAMs 1994, KRIST 2011). This species is a sedentary, hole-nesting and socially monogamous passerine bird (CRAMP 1998) and common species in my research area (Dolenec et al. 2011a). Data on changes in egg dimensions are relatively scarce, in comparison with data on other breeding parameters (СRICK 2004). 


\section{MATERIAL AND METHODS}

Research took place in Mokrice village area $\left(46^{\circ} 00^{\prime} \mathrm{N}, 15^{\circ} 55^{\prime} \mathrm{E}\right.$; ca. $140 \mathrm{~m}$ above sea level) in north-western Croatia from 1980 to 2015. The study area is a small mixed farming area with arable land containing small forests (up to $10 \mathrm{ha}$ ). The relief is mostly undulating lowland. I studied tree sparrows breeding in nest-boxes that had the dimensions of approximately $12 \mathrm{~cm} \times 12 \mathrm{~cm} \times 25 \mathrm{~cm}$, the diameter of the entrance hole being $3.2 \mathrm{~cm}$. The birds bred in nest-boxes placed at a height of 2.5-4 m, and all nest-boxes had a sliding top that allowed monitoring of breeding events. Mean number of breeding pairs for study period varied from year to year between 15 to 30 nests ( mean $=23.8$ nests; total $=855$ ). The study area was visited daily during the breeding season. The study includes only first clutches. All eggs were measured ("Somet" callipers) to the nearest $0.01 \mathrm{~mm}$ (maximum length and maximum breadth). Egg volume $\left(\mathrm{cm}^{3}\right)$ was calculated from HoyT's (1979) formula: volume $(\mathrm{V})=0.51 \times$ length $(\mathrm{L}) \times$ breadth $(\mathrm{B})^{2}$. This method was previously used on many bird species (e.g. Dolenec et al. 2008, Dolenec et al. 2011a, Dolenec 2013, Bowers et al. 2015).

Meteorological data (mean March-April temperature, 1980-2015) were supplied by the station of Maksimir (123 m a.s.l.) - Meteorological Office in Zagreb, about ca. $20 \mathrm{~km}$ from the research area (March-April, mean $=9.2 \pm 1.37^{\circ} \mathrm{C}$; range $=6.5$ to $11.9{ }^{\circ} \mathrm{C}$ ). To evaluate the effect of climate on the egg size, I took into account temperature data from breeding grounds since local air spring temperatures are an important breeding parameter (e.g. HušEk \& AdAmík 2008, DoleneC et al. 2009, Dolenec \& Dolenec 2010b). Another climate parameter I used was precipitations (in millimetres). Average spring precipitation (March-April) in research period was $55.2($ range $=18.2$ to 97.9$)$.

All the statistics were performed on average values per year, and tested using Pearson's correlations with two tailed P-values. The threshold for statistical significance has been set at the $\mathrm{P}=0.05$ level. Statistical analyses were performed using the SPSS 13.0 statistical package. Dates were expressed as progressive days, where $1^{\text {st }}$ March $=1$.

\section{RESULTS}

Overall, 855 nests were analysed between 1980 and 2015 located in Mokrice area (north-western Croatia). Eggs averaged $19.0 \pm 0.32 \mathrm{~mm}$ (range $=18.4$ to 19.8 $\mathrm{mm}$ ) in length, $14.1 \pm 0.23 \mathrm{~mm}$ (range $=13.7$ to $14.5 \mathrm{~mm}$ ) in breadth and $1.93 \pm 0.06$ $\mathrm{cm}^{3}$ (range $=1.81$ to $\left.2.07 \mathrm{~cm}^{3}\right)$ in volume. Egg length $(\mathrm{r}=0.117, \mathrm{p}=0.496, \mathrm{n}=36$ ), egg breadth $(\mathrm{r}=-0.191, \mathrm{p}=0.267, \mathrm{n}=36)$ and egg volume $(\mathrm{r}=-0.192, \mathrm{p}=0.261$, $\mathrm{n}=36$ ) in the studied Tree Sparrow population did not decrease or increase over a 36-year period. Correlation between mean spring temperatures (March-April) and mean egg length $(r=-0.141, p=0.415, n=36)$, egg breadth $(r=-0.008, p=$ 
0.964, $\mathrm{n}=36)$ and egg volume $(\mathrm{r}=-0.058, \mathrm{p}=0.737, \mathrm{n}=36)$ were not significant. However, spring temperatures (means of March-April values) have risen significantly $(\mathrm{r}=0.537, \mathrm{p}=0.001, \mathrm{n}=36)$ from 1980 to 2015 in the research area, indicating a mean increase by $2.52{ }^{\circ} \mathrm{C}$ (slope $=0.07$; Figure 1$)$. Relationship between mean spring precipitations (March-April) and mean egg length $(\mathrm{r}=0.071, \mathrm{p}=$ $0.682, \mathrm{n}=36)$, egg breadth $(\mathrm{r}=0.081, \mathrm{p}=0.641, \mathrm{n}=36)$ and egg volume $(\mathrm{r}=0.156$, $\mathrm{p}=0.362 . \mathrm{n}=36$ ) were not significant. Mean spring precipitations (March-April) did not change systematically during 1980-2015 $(\mathrm{r}=0.053, \mathrm{p}=0.761, \mathrm{n}=36)$.

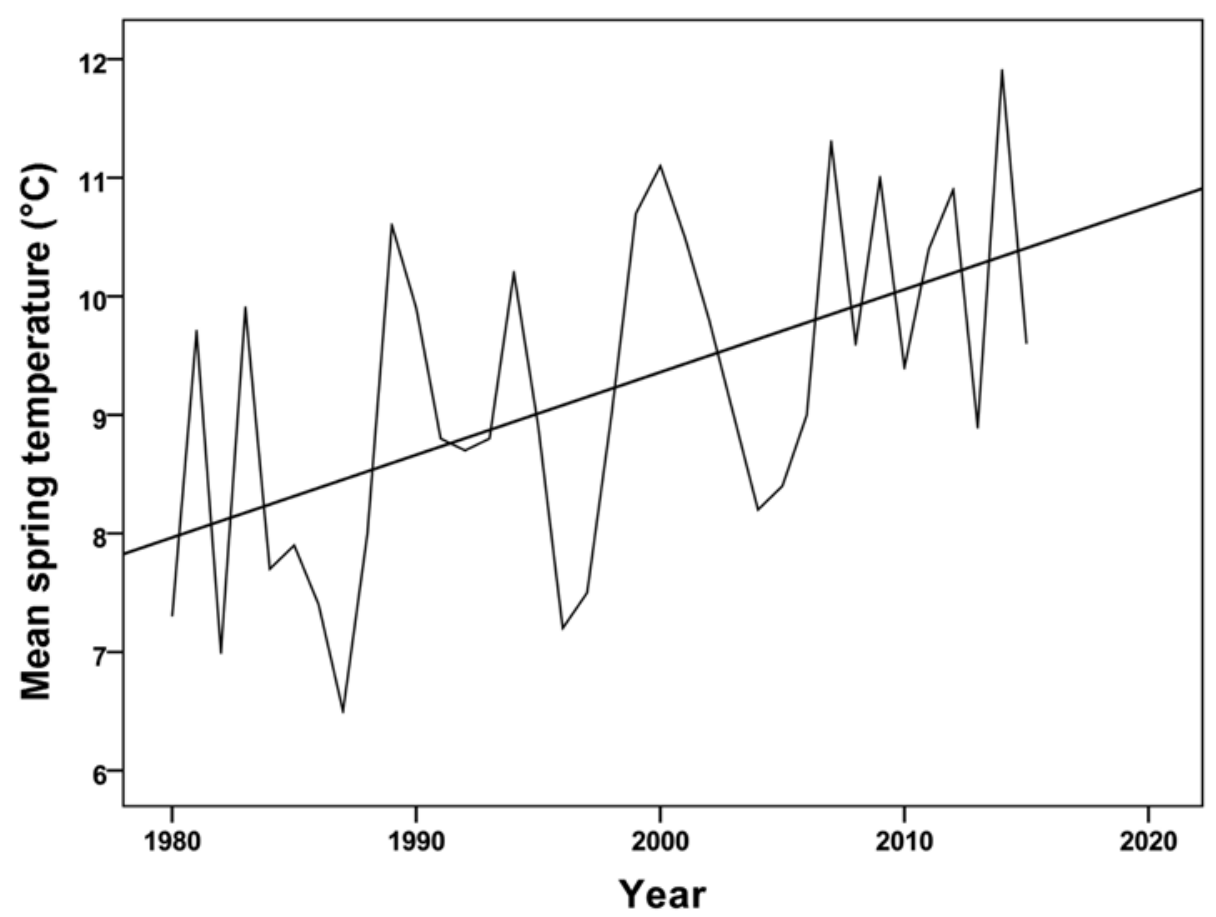

Figure 1. Increase in the mean temperature in March-April from 1980 to $2015(r=0.537, p=$ $0.001, n=36$ ). Meteorological data were supplied by the station of Maksimir - Meteorological Office in Zagreb.

Slika 1. Porast srednje temperature u ožujku i travnju od 1980. do 2015. ( $r=0.537, p$ $=0.001, n=36)$. Meteorološki podaci dobiveni su za postaju Maksimir od Državnog hidrometeorološkog zavoda u Zagrebu.

\section{DISCUSSION}

Laying dates of Tree Sparrow have advanced significantly in this area, while clutch size did not change (Dolenec et al. 2011b). Results of this study have shown that there has been no increase or decrease in egg dimension either. Significant growth of spring temperatures (March-April) in study period had 
no influence on average egg dimensions (length, breadth and volume). Spring precipitation (March-April) did not change over the years and did not effect of egg dimensions. The importance of precipitation patterns change for animals remains poorly understood (e.g. GoRdo 2007). So far, relatively few studies have examined the impact of climate change on egg dimensions, and the results appear to be variable. According to Pотті (2008), in Pied Flycatcher Ficedula hypoleuca, population analyses demonstrate that egg breadth, yet not egg length, has decreased significantly along the 16-year period, leading to marginally nonsignificant decreases in egg volume. TRYJANOwsKi et al. (2004) found a decrease of mean egg size with warmer temperatures in Polish populations of Red-backed Shrike (Lanius collurio), while Järvinen (1994) found exactly the opposite trend in a Pied Flycatcher (Ficedula hypoleuca) population in Finland. According to TRYJANOWSKI et al. (2004), predictions about the consequences of climate warming on egg size are not straightforward; this is because climate change is only one of the traits that may have impact on egg size; other traits such as female condition, individual size, genetic characteristics, habitat characteristics etc. should also be taken into consideration (e.g. Christians 2002, Both \& Visser 2005, Dolenec et al. 2007). Ornithology has provided several of the best examples of the effects of recent climate change on wildlife from around the world. We have, however, only begun to scratch the surface (СRICK 2004).

\section{ACKNOWLEDGMENTS}

I would like to thank two referees and the Editor for comments and improving the manuscript. The research was financially supported by grants from the Croatian Ministry of Science, Education and Sports (project no. 119-10126821221). I also thank the Meteorological Office in Zagreb for providing the spring temperature and precipitation data.

\section{References}

Barret, R. T., Nilsen, E. B., Anker-Nilssen, T. (2012): Long-term decline in egg size of Atlantic puffins Fratercula arctica is related to changes in forage fish stocks and climate conditions. Mar. Ecol. Prog. Ser. 457: 1-10.

Вотн, C., Visser, M. E. (2005): The effect of climate change on the correlation between avian life-history traits. Global Change Biol. 11: 1-8.

Bowers, E. K., White, A. Lang, A., Podgorski, L., Thompson, C. F., Sakaluk, S. K., Jaeckle, W. B., Harper, R. G. (2015): Eggshell porosity covaries with egg size among female House Wrens (Troglodytes aedon) but is unrelated to incubation onset and egg-laying order within clutches. Can. J. Zool. 93: 421-425.

Cramp, S. (1998): Complete Birds of Western Palaearctic's on CD-ROM. Oxford University Press, Oxford.

CRICK, H. Q. P. (2004): The impact of climate change on birds. Ibis 146 (Suppl. 1): 48-56. 
Christians, J. K. (2002): Avian egg size: variations within species and on flexibility within individuals. Biol. Rev. 77: 1-26.

D’Alba, L., Monagham, P., Nager, R. G. (2010): Advances in laying date and increasing population size suggest positive responses to climate change in Common Eiders Somateria mollisima in Iceland. Ibis 152: 19-28.

Dolenec, P., Kocijan, I., Dolenec, Z. (2011a): Intra-seasonal changes in reproductive strategy of a multi brooded passerine: the tree sparrow, Passer montanus. Ethol. Ecol. Evol. 23: 368-374.

Dolenec, Z. (2009): Impact of local air temperatures on the brood size in Starling (Sturnus vulgaris L.). Pol. J. Ecol. 57: 817-820.

Dolenec, Z. (2012): Non-significant trends towards earlier or later arrival date of the Pied Wagtail (Motacilla alba L.) in NW Croatia. Pol. J. Ecol. 60: 581-584.

Dolenec, Z. (2013a): Monitoring of the arrival time in the barn swallow (Hirundo rustica) population from Mokrice village (Croatia), 1980-2011. Nat. Croat. 22: 183-187.

Dolenec, Z. (2013b): Some breeding traits of the Pied Wagtail (Motacilla alba) in NW Croatia. Nat. Croat. 20: 2009-2014.

DolenEc, Z. (2015): Relationship between spring migration, temperature and year in the Common Starling Sturnus vulgaris. Larus 50: 29-36.

Dolenec, Z., Dolenec, P. (2010a): Changes in spring migration of the wood pigeon (Columba palumbus) in northwestern Croatia. Turk. J. Zool. 34: 267-269.

Dolenec, Z., Dolenec, P. (2010b): Response of the Blackcap (Sylvia atricapilla L.) to temperature change. Pol. J. Ecol. 58: 605-608.

Dolenec, Z., Dolenec, P. (2011a): Influence of the local spring warming on the breeding phenology in blackcap (Sylvia atricapilla) in Croatia. J. Environ. Biol. 35: 625-627.

Dolenec, Z., Dolenec, P. (2011b): Spring migration characteristics of the House Martin, Delichon urbica (Aves: Hirundinidae) in Croatia: A response to climate change? Zoologia (Curitiba) 28: 139-141.

Dolenec, Z., Dolenec, P., Møller, A. P. (2011b): Warmer springs, laying date and clutch size of tree sparrows Passer montanus in Croatia. Curr. Zool. 57: 414-418.

Dolenec, Z., Dolenec, P., KralJ, J. (2012): Egg-laying trends in black redstart (Phoenicurus ochruros). Curr. Sci. 102: 970-972.

Dolenec, Z., Delić, A., Kralj, J., Dolenec, P. (2007): Variation in egg dimensions of the Tree Sparrow (Passer montanus L.) in nothwestern Croatia. Pol. J. Ecol. 55: 841-845.

Dolenec, Z., Dolenec, P., Kralj, J., Kiš-NovaK, D. (2009): Long-term trends in timing of breeding of the Barn Swallow Hirundo rustica in Croatia. Pol. J. Ecol. 57: 611-614.

Dolenec, Z., Kralj, J., Mustafić, P., Dolenec, P. (2008): Female biometrical characteristic and egg dimensions of the Starling (Sturnus vulgaris L.) in Croatia. Pol. J. Ecol. 56: 545-548.

Dunn, P. O., Winkler, D. W. (1999): Climate change has affected the breeding date of tree swallows throughout North America. Proc. Roy. Soc. Lond. B - Biol. Sci. 266: 2487-2490.

Gordo, O. (2007): Why are bird migration dates shifting? A review of weather and climate effects on avian migratory phenology. Climate Research 35: 37-58. 
Hõrak, P., Mänd R., Ots I., Laivitis, A. (1995): Egg size in the Great Tit Parus major: individual, habitat and geographic differences. Ornis Fennica 72: 97-114.

Hušek, J., Арамíк, P. (2008): Long-term trends in the timing of breeding and brood size in the Red-Backed Shrike Lanius collurio in the Czech Republic, 1964-2004. J. Orn. 149: 97-103.

Inouye, D. W., Barr, B., Armitage, K. B., Inouye B. D. (2000): Climate change is affecting altitudinal migrants and hibernating species. Proc. Nat. Acad. Sci. USA 97: 1630-1633.

IPCC, (2007): Climate Change 2007: The Physical Science Basis. Contribution of Working Group I to the Fourth Assessment Report of the Intergovernmental Panel on Climate Change (eds. S. Solomon, D. Qin, M. Manning, Z. Chen, M. Marquis, K.B. Averyt, M. Tignor \& H.L. Miller ) Cambridge University Press, Cambridge, UK.

Jiménez-Valverde, A., Barve, N. Lira-Noriega, A., Maher, S. P., Nakazawa, Y., Papes, M., Soberon, J., Sukumaran, J., Peterson, T. (2011): Dominant climate influences on North American bird distributions._Global Ecol. Biogeogr. 20: 114-118.

Ноут, D. F. (1979): Practical methods of estimating volume and fresh weight of bird eggs. Auk 96: 73-77.

Järvinen, A. (1994): Global warming and egg size of birds. Ecography 17: 108-110.

JÄrvinen, A. (1996): Correlation between egg size and clutch size in the Pied Flycatcher Ficedula hypoleuca in cold and warm summers. Ibis 138: 620-623.

KRAlJ, J., Dolenec, Z. (2008): First arrival dates of the Nightingale (Luscinia megarhinchos) to Central Croatia in the early 20 century and at the turn of the 21 century. Cent. Eur. J. Biol. 3: 295-298.

KRIST, M. (2011): Egg size and offspring quality: a meta-analysis in birds. Biol. Rev. 86: 692-716.

Møller, A. P. (2002): North Atlantic Oscillation (NAO) effects of climate on the relative importance of first and second clutches in a migratory passerine bird. J. Animal Ecol. 71: 201-210.

Ротті, J. (2008): Temperature during egg formation and the effect of climate warming on egg size in a small songbird. Acta Oecol. 33: 387-393.

Thomas, C. D., Lennon, J. J. (1999): Birds extend their ranges northwards. Nature 399: 213.

Tryjanowski, P., Sparks, T. H., KuczyŃSki, L., KuzŃiAK, S. (2004): Should avian egg size increase as a result of global warming? A case study using the red-backed shrike (Lanius collurio). J. Orn. 145: 264-268.

Tryjanowski, P., Rybacki, M., Sparks, T. (2003): Changes in the first spawing dates of common frogs and common toads in Western Poland in 1978-2002. Ann. Zool. Fennici 40: 459-464.

Weidinger, K., Kral, M. (2007): Climatic effects on arrival and laying dates in a longdistance migrant, the collared flycatcher Ficedula albicollis. Ibis 149: 836-847.

Williams, T. D. (1994): Intraspecific variation in egg size and composition on birds: their influence on variation in life history tactics. Am. Nat. 128: 137-142. 


\section{SAŽETAK}

U posljednjih dvadesetak godina sve više radova dokumentira utjecaj klimatskih promjena kako na pojedine vrste tako i na cijele ekosustave. U ovome radu dati su rezultati dugogodišnjeg uzorkovanja dimenzija jaja (duljina, širina i volumen) populacije poljskog vrapca u odnosu na srednje proljetne temperature (ožujak-travanj) i srednju količinu padalina (ožujak-travanj) tijekom 36-godišnjeg razdoblja. Općenito, o utjecaju okolišnih čimbenika na dimenzije jaja ima malo objavljenih radova. Uzorkovanja u ovome radu obavljena su na području sela Mokrice (sjeverozapadna Hrvatska) u razdoblju od 1980. do 2015. godine. Proljetne su temperature u prosjeku značajno porasle $u$ istraživanom razdoblju dok u padalina nije bilo promjena. Međutim, nije došlo do odgovora na porast srednje proljetne temperature (ožujak-travanj) u istraživane populacije u smislu povećanja ili smanjenja dimenzija jaja. Rezultati istraživanja u ovom području demografije ptica su oskudni i u nekim slučajevima kontradiktorni. Neki autori govore o povećanju prosječne veličine jaja, dok drugi govore o smanjenju veličine jaja u nekih vrsta ptica kao odgovor na porast temperature. Očito, veličina jaja u ptica složeno je pitanje budući da je tu uključeno i niz drugih čimbenika osim sve toplijih proljeća, primjerice stanje ženke, genetička komponenta, obilježja staništa itd. 